\title{
ARVICOLA RUBRICATUS.-RIсн.
}

Red-Sided Meadow Mouse.

A. Supra obscurè plumbeus; subtus pallidè cinereus, lateribus miniatis, caudâ breviusculâ, pollice minimo.

\section{CHARACTERS.}

Back slate-coloured, belly ash-coloured, sides nearly scarlet, tail rather short. Thumb of fore foot rudimentary. Size a little greater than that of the common domestic mouse.

SYNONYME.

Arvicola rubricatus,-Rich. Zool. Beechey's Voy., Mammalia, p. 7.

The above are the characters of a meadow mouse, which burrows in the turfy soil on the shores of Behring's Straits, drawn up from Mr. Collie's notes. In the colours of its fur, and dimensions, it most resembles the Arvicola aconomus (PALL. glir. n. 125., pl. 14, A.), and appears to be quite distinct from any American meadow mouse hitherto described. There is no specimen in the collection. (Richardson.)

VOL. $\mathrm{III},-38$ 


\section{$2 \mathrm{BHL}$ Biodiversity Heritage Library}

Audubon, John James and Bachman, John. 1854. "Arvicola rubricates, Red-sided Meadow Mouse." The quadrupeds of North America 3, 297-297. https://doi.org/10.5962/p.322372.

View This Item Online: https://www.biodiversitylibrary.org/item/108515

DOI: https://doi.org/10.5962/p.322372

Permalink: https://www.biodiversitylibrary.org/partpdf/322372

\section{Holding Institution}

Duke University Libraries (archive.org)

\section{Sponsored by}

Duke University Libraries

\section{Copyright \& Reuse}

Copyright Status: Not provided. Contact Holding Institution to verify copyright status.

This document was created from content at the Biodiversity Heritage Library, the world's largest open access digital library for biodiversity literature and archives. Visit BHL at https://www.biodiversitylibrary.org. 